\author{
L.M. Pavlichenko ${ }^{\infty}$, A.P Yespolayeva ${ }^{\infty}$, \\ A.S. Aktymbayeva ${ }^{1 *}$, H. Jones ${ }^{2}$ \\ ${ }^{1}$ Al-Farabi Kazakh National University, Kazakhstan, Almaty \\ ${ }^{2}$ Middlesex University, United Kingdom, London \\ *e-mail: aliya.aktymbayeva@kaznu.kz
}

\title{
ESTIMATION OF THE ACCURACY OF INVERSE PROBLEM SOLUTION OF COMPLEX GENERALIZED ENVIRONMENTAL ESTIMATION BASED ON CARTOGRAPHIC INFORMATION
}

The article presents the results of the accuracy assessment of the method of generalized integrated assessment for solving the inverse problem of a comprehensive environmental assessment of territories. It is called the generalized assessment because the objective functions include the numerical expression of the sums of the areas of each level of anthropogenic disturbance, first throughout the region, and then for areas with an oil and gas producing complex, referred to the area of the whole region or the sum of the areas of zones with an oil and gas production complexes.

For the completeness of the perception-of-the-method, the-article-also describes methods for obtaining particular and private target functions, on the basis of which a generalized estimate is constructed Loads of transformation levels in private objective functions take into account the level of complexity of environmental protection measures for each component-of-the natural environment. The substantiation of weight loads in the private target functions is based on a review-of-literary sources analyzing intrasystemic relationships in the natural environment. The impact of the possible subjectivity of expert assessments in determining the loads (role) of the components of the environment in integrated environmental assessments in the form of objective functions is assessed by comparing various options for their sets.

The-calculation-of-results showed that the proposed method for the generalized solution of the inverse problem of a comprehensive environmental-assessment-of-the-territory practically does not respond to changes in the loads on the components of-the environment, since this influence is leveled out by the procedure of subtracting the integral target function throughout the territory from its analogue for zones with oil and gas production complex.

Key words: Mangystau region, oil and gas producing complex, the degree of anthropogenic disturbance, generalized private objective functions, assessment of the accuracy of solving the inverse problem of integrated environmental assessment of the territory.

\author{
А.М. Павличенко ${ }^{1}$, А.Р. Есполаева ${ }^{1}$, А.С. Актымбаева ${ }^{1 *}$, Н. Jones² \\ 'Ә^-Фараби атындағы Қазақ, ұлттық, университеті, Қазақстан, Алматы қ. \\ ${ }^{2}$ Миллсекс Университеті, Ұлыбритания, Аондон қ. \\ *e-mail: aliya.aktymbayeva@kaznu.kz \\ Картографикалық ақпаратқа негізделген жалпы интеграцияланған \\ қоршаған ортаны бағалауда «кері мәселе» Аәлекін анықтау
}

Мақалада аумақтарды кешенді экологиялық бағалаудың кері мәселесін шешу үшін жалпыланған кешенді бағалау әдісінің дәлдігін бағалау нәтижелері келтірілген. Жалпылама бағалау деп аталу себебі, өйткені объективті функцияларға антропогендік бұзылыстың әр деңгейінің аудандарының сандық ауданы кіреді, алдымен бүкіл аймақта, содан кейін мұнай мен газ кен орындары бар аймақтар үшін, олар бүкіл аймақтың немесе мұнай мен газ кен орындары бар аймақтардың жиынтығына жатады.

ӘАістің қабылдануы толықтығы үшін мақалада нақты және интегралды объективті функцияларды алу әдістері сипатталған, олардың негізінде жалпыланған бағалау құрылады. Жеке мақсатты функциялардағы трансформация деңгейінің жүктемелері табиғи ортаның әр компоненті бойынша қоршаған ортаны қорғау шараларының күрделілік деңгейін ескереді. Интегралды объективті функциялардағы салмақтық жүктемелердің негізделуі табиғи ортадағы интрасистемалық қатынастарды талдайтын әдеби көздерді шолуға негізделген. Объективті функциялар түрінде кешенАі экологиялық бағалаудағы қоршаған орта компоненттерінің жүктемелерін (рөлін) анықтауда сараптамалық бағалаулардың мүмкін субъективтілігінің әсерін олардың жиынтығына арналған әртүрлі нұсқаларды салыстыру арқылы жүзеге асырылады. 
Есептеудің нәтижелері аумақты кешенді экологиялық бағалаудың кері есептерін жалпылама шешудің ұсынылған әдісі іс жүзінде қоршаған орта компоненттеріне түсетін жүктемелердің өзгеруіне жауап бермейлі, өйткені бұл әсер мұнай-газ өндіру кешені бар аймақтар үшін оның аналогынан оның интегралды объективті функциясын бөлу процедурасымен теңестірілген.

Түйін сөздер: Маңғыстау облысы, мұнай және газ өндіру кешені, антропогендік бұзылу Аәрежесі, жалпыланған жеке объективті функциялар, аумақты кешенді экологиялық, бағалаудың кері мәселесін шешудің дәлдігін бағалау.

\author{
А.М. Павличенко ${ }^{1}$, А.Р. Есполаева ${ }^{1}$, А.С. Актымбаева ${ }^{1 *}$, Н. Jones ${ }^{2}$ \\ ${ }^{1}$ Казахский национальный университет им. аль-Фараби, Казахстан, г. Алматы, \\ ${ }^{2}$ Миллсекс Университет, Великобритания, г. АонАон \\ *e-mail: aliya.aktymbayeva@kaznu.kz \\ Оценка точности решения обратной задачи обобщенной \\ комплексной экологической оценки на основе картографической информации
}

\begin{abstract}
В статье представлены результаты оценки точности метода обобщенной интегральной оценки Аля решения обратной задачи комплексной экологической оценки территорий. Обобщенной оценка названа потому, что в целевые функции входят числовые выражения сумм площадей каждого уровня антропогенной нарушенности сначала по всей территории области, а потом Аля зон с наличием нефтегазодобывающим комплексом (НГАК), отнесенные к п^ощади всей области или сумме площаАей зон с НГАК.

Аля полноты восприятия метода в статье изложены также методики получения частных и интегральных целевых функций, на основе которых строится обобщенная оценка. Нагрузки на уровни трансформации в частных целевых функциях учитывают уровень сложности проведения природоохранных мероприятий по каждому компоненту природной среды. Обоснование весовых нагрузок в интегральных целевых функциях выполнено на основе обзора литературных источников, анализирующих внутрисистемные взаимосвязи в природной среде. Оценка влияния возможного субъективизма экспертных оценок при определении нагрузок (роли) компонентов природной среды в интегральных экологических оценках в форме целевых функций проводится путем сравнения различных вариантов их наборов.

Результаты расчетов показали, что предложенный метод обобщенного решения обратной задачи комплексной экологической оценки территории практически не реагирует на изменения нагрузок на компоненты природной среды, поскольку это влияние нивелируется процедурой вычитания интегральной целевой функции по всей территории из ее аналога по зонам с НГАК.

Кмючевые слова: Мангистауская область, нефтегазодобывающий комплекс, степень антропогенной нарушенности, обобщенные частные целевые функции, оценка точности решения обратной задачи комплексной экологической оценки территории.
\end{abstract}

\section{Introduction}

The region is located in the southwest of the Republic of Kazakhstan in the desert zone and includes the of Mangyshlak Peninsula, Ustyurt plateau, Buzachi peninsula, Dead Kuluk and Kaidak sars and is characterized by continental dry desert climate, strong storms and winds. Most of the territory of the Mangystau region is dominated by east and south-east winds in winter, and in the west by western and north-western winds. The average annual wind speed is $3-7 \mathrm{~m} / \mathrm{s}$, the maximum reaches $10-26 \mathrm{~m} / \mathrm{s}$, winds of a hurricane character with a speed of more than $15 \mathrm{~m} / \mathrm{s}$ are observed on the coast in winter (Pavlichenko 2015: 133).
Most of the territory of the region is occupied by wormwood-solonchak desert with areas of shrub vegetation on brown soils: the surface is partially covered with solonchaks, takyr-like solonetzes and sands with extremely rare vegetation. Thus, the climatic conditions of the Mangystau region predetermine the development of deflation and sorption processes, the formation of a poor soil and vegetation cover with a low ability to mitigate the effects of anthropogenic impacts.

Specificity of climatic conditions of the region, taking into account the complete absence of constant river flow, causes the severity of the problem of water resources shortage, and, first of all, the shortage of drinking water. According to experts, the shortage of drinking water in the 
Mangystau region is $40,000 \mathrm{~m} 3$ per day, and by 2020 will reach 70,000 m3 / day (Pavlichenko 2015: 133).

There are 559 industrial enterprises registered in the region, of which 70 are large and medium. The raw orientation of the regional economy has predetermined the priority of the extractive industry, the development of which is directly dependent on all other sectors of the economy. The region occupies the third place in the republic in terms of the total volume of industrial production. At the core of the region's economy is the oil and gas sector, which production accounts for more than 90 percent of the total industrial output in the region, which explains the attitude towards the oil gas producing complex as the main source of anthropogenic disturbance of the natural environment components, since the oil and gas industry is traditionally considered one of the most environmentally dangerous industries (Pavlichenko 2015: 133).

The natural conditions of the regions in combination with the anthropogenic load determine their ecological situation. The ecological condition of the territories is assessed based on the results of a different type of monitoring of the components of the natural environment. Technical means of monitoring reflect the influence of many sources of anthropogenic impact on the state of the air, soil, vegetation, relief, surface and groundwater through a number of measured parameters. These parameters are the basis for the construction of complex (by all components) or partial (for individual components) environmental assessments of the natural environment. The complexity of the task of constructing complex and private environmental assessments has led to the lack of generally accepted methods for solving it. However, for the objective implementation of the polluter pays principle, an independent assessment of the contribution of individual sources to these complex or private environmental assessments is necessary, that is, a search for a solution to the inverse problem of a complex (or private) environmental assessment.

The solution of this problem is the aim of the authors who conducted grant funding project of the Ministry of Education and Science of the Republic of Kazakhstan №0589 / GF-4 Development of a method for objectifying expert assessments of the contribution of individual pollution sources to the general environmental situation of the territory. As part of the project a number of works were carried out, amoung which project are published articles
(Pavlichenko 2016: 117) They consider examples of solving the inverse problem for assessing the contribution of the activities of the oil gas production complex of the Mangystau region to anthropogenic modifications of the most important components of the natural environment and the actual data for their confirmation.

The purpose of this paper is to estimate the accuracy of the method of generalized solution of the inverse problem of complex ecological assessment of the territory proposed by the authors in two ways: 1) by comparing the results of the solution for different options of expert sets of loads (role) of the components of the natural environment in integral environmental assessments in the form of objective functions to identify the effect and 2) the different composition of the original cartographic material.

\section{Material and Research Methods}

The method of generalized integrated assessment is based on the use of ready-made maps, which are expert private environmental assessments of the anthropogenic transformation of the components of the environment and are implemented by three methods.

Method 1 is aimed at obtaining specific evidence in a quantitative form, adapted for use in objective functions, and substantiating sufficient objectivity of expert assessment cards used to obtain actual material. To convert initial cartographic (dispersed) information into quantitative (concentrated) for private purpose-oriented functions, GIS technologies were used. To simplify and accelerate the procedure for obtaining actual numerical data, ArcGIS components were used: on vector shapefiles, the area values of the contours are displayed automatically. The imposition of a layer of oil-gas production complex on each assessment map allows determining spreading areas of five levels of anthropogenic impact on the components of the natural environment within the circuits of the oil-gas production complex.

Method 2 is based on the idea of finding particular solution of the inverse problem of a private integrated environmental assessment as the difference of particular generalized objective functions reflecting the average (average weighted) estimates of anthropogenic impact on the components of the natural environment as a whole in the Mangystau region of the Republic of Kazakhstan and for zones with the presence of an oil-gas production complex. 
Method 3 is used generalized integral solutions of the "reverse" tasks of a comprehensive environmental assessment as the difference of integrated generalized objective functions that reflect the average (weighted) estimates of the anthropogenic impact on all components of the environment as a whole in the Mangystau region of the Republic of Kazakhstan and for zones with the presence of oil-gas production complex.

The considered method of solving the "inverse" tasks initially assumes the availability of readymade complex expert assessments of the ecological state of the Mangystau region, therefore, as an initial material, evaluation maps of the anthropogenic impact on the components of the natural environment from the published "Atlas of the Mangystau region" (Atlas: 2011). These are the maps "Anthropogenic impact on the relief", "Anthropogenic transformation of vegetation", "Degradation of soil cover", "Anthropogenic disturbance of groundwater" and "Natural protection of groundwater". To reflect the influence of the oil gas producing complex on each component of the natural environment, an inventory map was used from the Atlas "Anthropogenic sources of impact" (Figure 1). The maps were constructed by the Institute of Geography of the Ministry of Education and Science of the Republic of Kazakhstan on the basis of expert assessments of materials of expeditionary research and interpretation of remote sensing data of the territory. In described parts of the legend to the inventory map noted that the Mangystau region is a region for the development of powerful industrial production of various sources of the economy, as well as a place for conducting nuclear tests, which led to a complication of the ecological situation. Historical pollution continues to have a negative impact on the environment and the medical and demographic situation (the conventional signs of anthropogenic sources of exposure are shown in Figure 1). The main sources of anthropogenic impact on the environment in the region are industrial enterprises, confined to cities, workers' settlements, oil and gas fields.

In the territory of Mangystau region, 218 quarries are being developed, exploration and production of common minerals - clays for the production of drilling muds, self-planting salt, sand-gravel mixture, chalk, construction sand, limestone-rock, stone, sandstone, marl, and production of oil, gas and associated recoverable components (Figure 1). Special signs on the inventory map shows the location of anthropogenic sources of air, water and soil pollution (Figure 1). The place of location of different industry of the regional economy is noted:

Extractive industry - oil production, gas production, oil and gas production; Mining, extraction and enrichment of non-metallic ores, extraction and production of salt, extraction of saw stones, building stones, clay brick, chalk, sand, sand-gravel mixture;

manufacturing industry - machine building and metalworking, chemical;

Local and food industry;

Production of nuclear power;

Road construction

Housing and communal services.

Also, the map shows radioactive waste disposal sites (the tailing dump Koshkarata), storage bins for oiled soils, waste water storage tanks, solid industrial and household waste, man-made pollution of soils and the location of underground nuclear explosions, oil pipelines, gas pipelines, railways and highways, location of the airport and seaport (Figure 1).

Such an extensive list of impact to anthropogenic sources on the components of the natural environment is a serious justification for the objectivity of expert assessment maps of anthropogenic impact. Nevertheless, in the analysis of each of the evaluation maps, a legend was also considered, reflecting the zoning criteria according to the levels of anthropogenic impact.

The next step is taking the initial data for constructing generalized objective functions using a simplified (generalized) method to determine the areas of contours with different levels of anthropogenic impact, which are allocated on the evaluation maps in different colors in accordance with the legends of the corresponding maps. In fact, this procedure is the simplest way to transform of cartographic information into the quantitative. All of the evaluation maps present 5 levels of anthropogenic impact on the components of natural environment, however each level presented on the maps in a certain color has quite a few local closed circuits. In the generalized setting of the area, contours of the same color are summarized, and as a result, 5 sums of contour areas corresponding to 5 levels of anthropogenic disturbance of the environmental component are obtained for each map. The calculation of the areas of the contours of each level is carried out first across the entire region, and then for contours within the zones with the oil-gas production complex. 


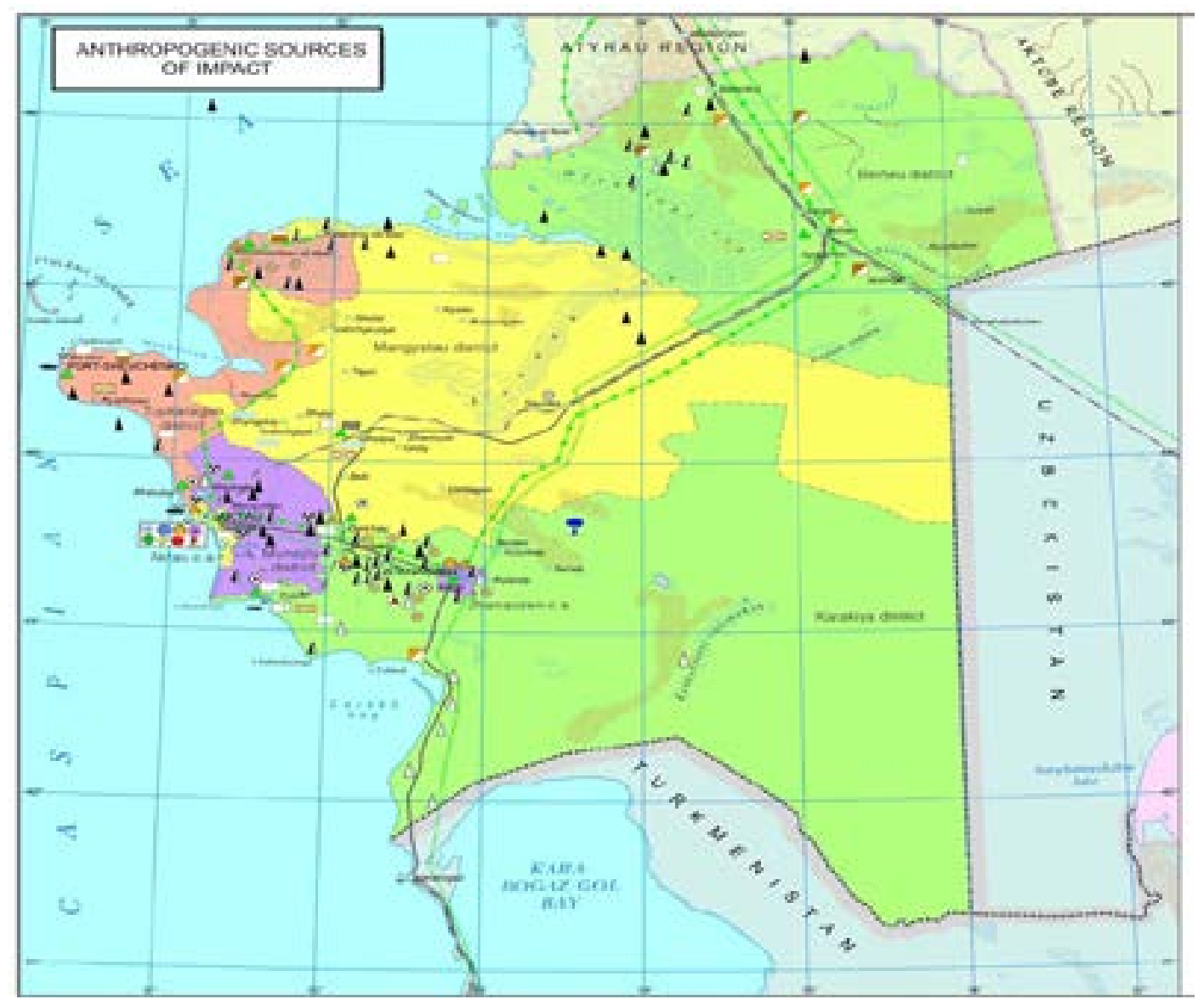

ANTMROPOGENIC SOURCES OF ATMOSPMERIC, WATER AND SOL CONTAMANATION BRARCMES OF IRDUETRY
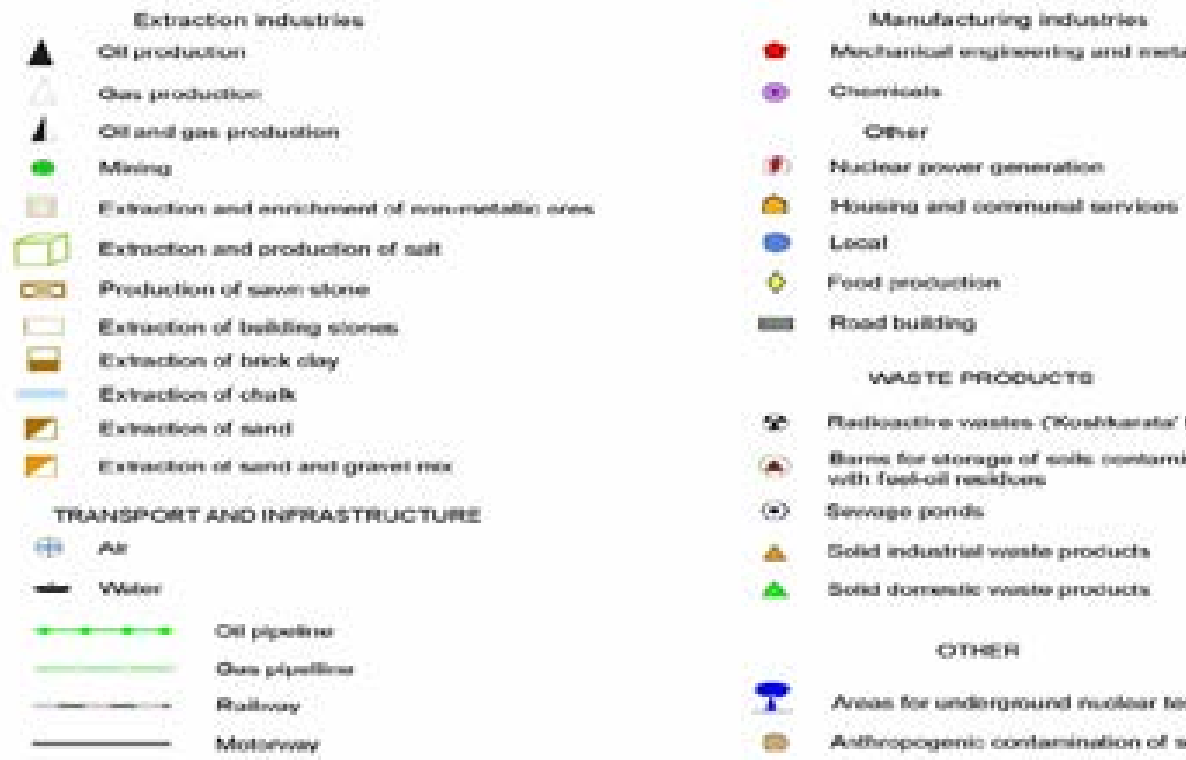

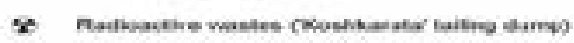

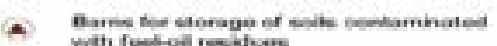

wath fuetolit ractiven

(*) Sewroe ronds

A Both molintried moste products

A seted dorrestic mintes products

\section{orren}

P. Neas ner undoromound molear hess

b Avthropogents comtarinetion of nots

Figure 1 - Inventory map of anthropogenic sources of impact on the natural environment of the Mangystau region (Atlas: 2011) 
The second method is based on the idea of constructing particular generalized objective functions reflecting the average (weighted average) estimates of anthropogenic impact on the components of the natural environment as a whole in the Mangystau region of the Republic of Kazakhstan and for zones with the presence of oilgas production complex, as well as particular generalized solutions of the inverse tasks of integrated environmental assessment for individual components of the natural environment.

The general view of the objective function, taking into account not only the intensity of the impact of each environmental factor, but also its role (importance) in the formation of favorable or negative conditions for the existence of biosystems, according to the proposal of R. Pantle, looks like the equation of linear multiple regression (1) (Pantle R.1979: 215).

$$
O F_{C E A}=a_{1} \cdot f_{1}+a_{2} \cdot f_{2}+\ldots+a_{n} \cdot f_{n}
$$

where $O F_{C E A}$-calculated value of the objective function for integrated environmental assessment;

$f_{i}$-value of a specific environmental factor $(\mathrm{i}=$ $1,2, \ldots, n)$ at the observation point;

$a_{i}$ - weighting factor that takes into account the direction (plus or minus sign relative to the goal) and the importance (weight) of this factor in the formation of the total level of impact.

In this formulation, the objective function is made not in the classical mathematical point (where it is understood as a criterion for comparing alternatives with the help of various optimization methods), but as a function that realizes the purpose of the assessment. The formal similarity with the mathematical meaning is also observed here - the optimization procedure is reduced to a search for the coefficients of the significance of ai (estimates are almost always expert) with an observance of the condition for their justification.

Objectivization of the target function includes justification of the selection of the most significant factors on the basis of taking into account specific geographic, ecological and economic conditions of the assessed territory and the completeness of the range of scoring scales. In (Avessalomova I.A. 1992), devoted to the popular presentation of the ideas of engineering ecology, a very simple formula (2) is given for calculating a sufficient number of parameters $\mathrm{n}$ (environmental factors in the above equation) with the desired accuracy of the estimate:

$$
\Delta=\frac{1}{l^{n}}
$$

where $l-$ level of quantization of scoring scales used in the assessment of environmental factors (the number of divisions of the scoring scale), and $\mathrm{n}$ is the number of factors involved in the assessment.

Previously, the most critical moment determining the degree of objectivity of integrated environmental assessments in ecological and geoecological studies was the construction of private scoring scales. Only each parameter from its available set is estimated on a scale constructed on the basis of independent studies of the entire possible range of its changes, it was allowed to speak about the objectivity of complex estimates (Avessalomova I.A. 1992).

It follows from formula (2) that even with the coarsest evaluation scale with a quantization level of 2 (that is, for an expert evaluation based on the principle of "yes" and "no"), it is possible to achieve sufficient accuracy with 5 parameters taken into account $(\square=1 / 25=0.03125$, or $3.1 \%)$. Thus, the number of analyzed parameters $\mathrm{n}$ (the exponent in the denominator of the formula), rather than the quantization level of the scales 1 (the number of divisions in our measuring "ruler") exerts a greater influence on the accuracy (actually on the objectivity) of the expert estimates. Thus, the analysis of formula (2) from the standpoint of the general theory of systems and the quantitative theory of information has shown that the degree of differentiation of the scale and the completeness of the range of all possible states of the considered parameter plays a subordinate role when using the multidimensional estimator function (Jeffers J. :1981)Therefore, doubts about the objectivity of scoring scales due to the complexity of taking into account nonlinear interaction effects with other factors when using the multidimensional linear regression equation as a model of the objective function can be removed by increasing the number of factors chosen as important for the description. It can be stated that in the problem of objectification purely expert approaches remained only when justifying the choice of the most significant factors.

The next step in the computational procedure is to substantiate the type of objective functions. Since we use ready-made assessment maps as the source of actual material, the objectivity and accuracy of which is unquestionable, the task of substantiating the assessment parameters becomes 
elementary - there are 5 colors on the map, each of which corresponds to a certain level of anthropogenic impact on individual components of the natural environment. Thus, the number of fi parameters in the objective function, which should describe the anthropogenic impact at all levels, is assumed to be 5, i.e. the number of anthropogenic impact levels highlighted on each of the assessment maps.

Justification of Now it remains to characteristics of the weight coefficient ai is required, taking into account the directivity (plus or minus sign) and the significance (weight) of the corresponding factor in the formation of the total impact level. Based on the purpose of the assessment - determining the role of OGPC in anthropogenic impact on individual components of the environment, positive we will be a sign signify direction of negative changes in natural components, which is reflected in all of the assessment maps.

We determine the weight loads of each parameter of the objective function provided that five levels of impact on individual components of the environment correspond to the traditional tenpoint scale in expert assessments. In the case of a linear scale, each of the 5 levels will have 2 points, and an increase in the level of transformation will correspond to an increase in the score.

This statement is substantiated from the standpoint of the complexity and cost of environmental protection measures, in particular measures for the restoration of the territory. Since the cost of environmental protection measures increases in proportion to the degree of anthropogenic disturbance (i.e., the ability of natural systems to heal), we will conduct a private environmental assessment of the contribution to each zone in accordance with a weight coefficient proportional to the level of transformation in a rating scale. In this case, the lower and upper boundaries of 5 levels (parameters of the objective function) are points:

for the level of non-significant transformation or its absence $-0 \div 2$;

for the level of weak transformation $-2 \div 4$;

for the level of moderate transformation $-4 \div 6$;

for the level of significant transformation $6 \div 8$,

for the level of strong transformation $-8 \div 10$.

Taking for average values of the contribution of the oil and gas production complex to the anthropogenic transformation of vegetation to the meaning between the values of the classes of values, we obtain the following form of the partial objective function for the overall assessment of the transformation of the $\mathrm{j}$-th component of the natural environment $\left(C N E_{j}\right)$ in region $\left(P O F_{C N E p j R e g}\right)$ :

$$
\begin{aligned}
& P O F_{C N E p j R e g}=f_{C N E p j R e g 1}+3 \cdot f_{C N E p j R e g 2}+ \\
& +5 \cdot f_{C N E p j R e g 3}+7 \cdot f_{C N E p j R e g}+9 \cdot{ }_{C N E p j R e g} 5
\end{aligned}
$$

where $f_{C N E p j R e g i}$ - function of the i-th level of anthropogenic disturbance of the jth component of the natural environment for the entire region, which is calculated by dividing the total area of polygons of the i-th level of anthropogenic transformation for this $\mathrm{j}$-th component in the whole region by the area of the whole region.

Should pay attention to the fact that as $f_{C N E p j R e g i}$ is not variables assigned to any part of the territory used, but specific values are the sums of all the contours of the same color (5 samples from the shapefile attribute table), referred to the area of the entire region. Therefore, as a result of solving equation (3), only 1 result will be obtained - a number characterizing the average weighted average level of anthropogenic transformation of the $j$-th component of the natural environment as a whole over the entire region - the value $P O F_{C N E p j R e g i}$.

To solve the particular inverse problem of a comprehensive environmental assessment by a generalized method, it is necessary to construct a similarly estimated function for areas with oil and gas producing complex. Since these areas are determined using the same evaluation map, the difference between the private objective function for the overall assessment of the anthropogenic impact on the environmental component of the region and the objective function for the field location zones $\left.\left(P O F_{C N E P j O G P C}\right)\right)$ will consist only in replacing the $f_{C N E p j R e g i}$ values with the $f_{C N E p j O G P C i}$ values. Now this is a function of the i-th level of anthropogenic disturbance of the $\mathrm{j}$-th component of the natural environment for the total area of zones with oil and gas producing complex, which is calculated by dividing the total area of polygons of the $\mathrm{i}$-th level of anthropogenic transformation for this $j$-th component for all zones with oil and gas producing complex, where this level is present, to the total area of all zones with oil and gas producing complex. Weight loads will remain the same as in equation (3):

$$
\begin{aligned}
& P O F_{C N E j O G P C}=f_{C N E j O G P C 1}+3 f_{C N E j O G P C 2}+ \\
& +5 f_{C N E j O G P C 3}+7 f_{C N E j O G P C 4}+9 f_{C N E j O G P C 5},
\end{aligned}
$$


As in (3), not variables will be obtained in equation (4), but the sums of all contours of the same color (5 samples from the shapefile attribute table) in the zones with OGPC, referred to the total area of all zones with OGPC. Therefore, as a result of the solution (4), only 1 result will be obtained $P O F_{C N E P J O G P C}$ - the number characterizing the average weighted average level of anthropogenic transformation of the jth component of the natural environment as a whole for all zones of influence of the OGPC.

The solution of the particular inverse problem of determining the role of NGDK in the transformation of each $\mathrm{j}$-th component of the natural environment of the Mangystau region as a whole is determined by subtracting the value of $P O F_{C N E j R e g}$. from the value of POF CNEpjOGPC equation (5).

$$
P S I P_{C N E p j}=P O F_{C N E j O G P C}-P O F_{C N E p j R e g}
$$

In this case, $P S I P_{C N E p j}$ characterizes a additional (since the $P O F_{C N E j R e g}$ reflects the total impact of all the main factors in accordance with the legends to the evaluation maps), the contribution of the OGPC to the anthropogenic disturbance of the $\mathrm{j}$-th component of the natural environment in the Mangystau region at all levels of anthropogenic transformation.

Consideration of the third methodology for the generalized solution of the inverse problem of a comprehensive environmental assessment is required- to obtain the form of integrated target functions for all components of the natural environment both throughout the Mangystau region and for zones with the presence of oil and gas production complex. The logic of constructing target functions does not change, but the semantic content of the factors included in equation (1) changes. Now in their capacity are private generalized target functions.

Private target functions are constructed by analogy with the partial way of replacing $f_{C N E j R e g i}$ by the POF ${ }_{C N E j R e g}$ in Eq. (3) and $f_{C N E j O G P C i}$ at the $P O F_{C N E P j O G P C}$ in equation (4). When constructing them, a new justification of the load values is necessary, since now the private objective functions constructed for all components of the natural environment of the Mangystau region (relief, soil, vegetation, and groundwater) both throughout the territory and for zones act as factors in the integral target function with the presence of OGPC.
As a result of changing the semantic content of the factors, we obtain equations (6) and (7).

$$
\begin{gathered}
I O F_{\text {re }}=a_{\text {rel }} P O F_{\text {rel Reg }}+a_{\text {soil }} P O F_{\text {SoilReg }}+ \\
+a_{\text {veg }} P O F_{V E G R e g}+a_{G W} P O F_{G W R e g} \\
I O F_{O G P C}=a_{\text {rel }} P O F_{\text {RelOGPC }}+a_{\text {soil }} P O F_{\text {soilOGPC }}+ \\
+a_{\text {veg }} P O F_{\text {vegOGPC }}+a_{G W} P O F_{G W O G P C}
\end{gathered}
$$

When substantiating weight loads, equations (6) and (7) take into account the role of each component in the anthropogenic transformation of the natural environment of the Mangistau region. This role is justified by experimental and theoretical studies of geosystems in the works of such classics in the field of Earth Sciences as Vernadsky V.I., Dokuchaev, V.V., Budyko M.I., Williams V.R., Kovda V.A., Armand D.L., Isachenko A.G., Alekin O.A., Solntsev V.N., Ahmedsafin U.M., Sydykov Zh.S., Sochava V.B. et al. (Pavlichenko 2015 :133). A noticeable contribution to the study of the formation of specific and general patterns of landscapes, soils, surface and underground waters was made by Milkov F.N., Rozanov B.G., Chigarkin A.V. Geldyeva G.V., Dzhanaleeva G.M., Posokhov E.V., Ostrovsky V.N., Dostay Zh.D., Gavich I.K., Perelman A.I., Shvartsev S.L., Goldberg V .M. and many others (Milkov F.N. 1990: 335), The formation factors of the components of the natural environment and their relationship are the subject of research by numerous scientists.

In the textbook of F.N. Milkova "General geography" (Milkov F.N. 1990: 335), which can be consideredas an encyclopedia on the formation of Landscape Science, notes that the importance of the lithogenic basis (geological structure and relief, according to RI Abolin) in the differentiation of the landscape sphere is universally recognized. Even the idea of a lithogenic base as the most "strong" component of the landscape has been put forward (N.A. Solntsev, 1960). This idea is F.N. Milkov criticizes, emphasizing the equivalence of landscape-forming factors on the example of V.V. Dokuchaev (1899) as applied to soil at the end of the 19th century and the teachings of L.S. Berg (1947) on the geographical landscape. Nevertheless, several sections of his manual emphasize the specificity of the relief as the most conservative factor that persists even with changing climatic characteristics, which gives reason to almost all geographical schools to consider the relief as a factor in the formation and spatial 
differentiation of landscapes (Milkov F.N. 1990: 335)

The role of soil as one of the components of the ecosystem that arose as a result of complex interaction of the atmosphere, hydrosphere, lithosphere, flora and fauna was considered in the works of V.V. Dokuchaev, Yu. Libikh, V.R. Volobueva, E.D. Russell, L.G. Ramensky, V.R. Williams, V.A. Kovdy et al. Modern soil science considers the soil not only as a result of the soilforming process, but also as a functional natural structure that plays a huge role in the ecosystem. It is now considered established that the stability of the ecological functions of soils is the main condition for the stability of the biosphere as a whole [28-30, 36-39], therefore the choice of soils as an indicator of the intensity of anthropogenic impact on the ecosystems of the Mangystau region can also be considered quite justified. In an interconnected system of landscape-forming factors, vegetation is the main functional block of the ecosystem, one of the most dynamic, responding to changes in the state of soils, and relief, and the water sphere, and the air environment (Milkov F.N. 1990: 335, Zhanaleeva G.M.,2001: 164) this role of vegetation is explained by the fact that it participates in the formation of soils, affects the cycle of matter and energy, and serves as a bioclimatic and environmental indicator. Its functions such as the accumulation of solar energy, the synthesis of organic substances, and the regulation of the gas balance of the biosphere ensure the existence of all living organisms. By its state, floristic and cerotic diversity, one can judge the speed and direction of anthropogenic and anthropogenic stimulated processes, the dynamics of other components of ecosystems (soils, ground and surface waters, etc.).

One of the most important factors in the formation of the natural environment is the climate, but its characteristics are zonal and it is impossible to differentiate it by the territory of the region. Climatic conditions are manifested through the specifics of the relationship of relief, soil, vegetation, surface and groundwater, and the air. In our research relief, soil, vegetation and groundwater were taken into account.

Anthropogenic changes in the air environment, even in terms of time-averaged parameters, are not possible to be differentiated across the entire Mangystau region due to the rare regional network of meteorological stations. Monitoring of air pollution, reflected in the newsletters, is carried out only at Dunga (3 points) and Zhetybai (3 points) deposits. But since the state of atmospheric air is primarily reflected in the state of vegetation, we can assume that this component takes this factor into account when constructing an assessment map of anthropogenic transformation of vegetation.

According to the Akimat, in the Mangistau region there are 60 rural settlements, of which 17 settlements are provided with centralized water supply, 35 are decentralized. Due to the small population and the economic inexpediency of building a water supply system, imported drinking water is used in 9 rural settlements. The cities of Aktau and Zhanaozen with adjacent settlements, as well as oil-producing enterprises consume $93 \%$ of the total volume of water, the share of settlements is $7 \%$.

Deficit problem of drinking water resources are solved mainly through desalinated Caspian water and Volga water coming from the Russian Federation. All this water is consumed by the cities of Aktau and Zhanaozen with surrounding settlements, as well as oil companies. Rural settlements throughout the region are supplied from local underground water deposits, therefore, an assessment of their ecological status is necessary. As the first approximation, the magnitude of the load itself in the integral objective function can be set by adjusting the expert assessment of the relative impact of factors. The next step in determining the loads is to normalize their sum (without taking into account the 1 directivity of the impact) per unit, ten or hundred, taking into account the difference in the effect of oil and gas production on each of the components of the natural environment.

Since all components of the environment are interconnected in the geo-ecosystem, and each component affects the others, we refer to the experience of the geo-ecological assessment of these relationships (Jeffers:1981:213), where the regulatory role of vegetation and approximately the same roles of soils and relief are affirmed, although the mechanism of their manifestation is much different. Of course, in arid conditions, the role of water is great, and in the absence of surface waterways and ponds, groundwater becomes an important source of moisture supply to vegetation. However, the lack of surface water sources affects their quality and availability for plants - they become salty and deep.

Since evaporation from a groundwater in loose rocks is possible from a depth of $3 \mathrm{~m}$, only plants 
with long roots can get such water, and only hodgepodge can be used, which is usually noted in the list of species composition.

Given these estimates, the equation for calculating a comprehensive environmental assessment of the (total) impact of last equation can be rewritten in the form (subject to normalizing the sum of the loads by 1$)$ :

$$
\begin{gathered}
I O F_{\text {Reg }}=0,24 P O F_{\text {Rel Reg }}+0,24 P O F_{\text {soilReg }}+ \\
+0,28 P O F_{\text {VegReg }}+0,24 P O F_{\text {GWReg }} \\
\begin{array}{c}
I O F_{O G P C}=0,24 P O F_{\text {RelOGPC }}+0,24 P O F_{\text {soiloGPC }}+ \\
+0,28 P O F_{\text {veg } O G P C}+0,24 P O F_{G W O G P C}
\end{array}
\end{gathered}
$$

It is clear that the selected from literary source of load has an exclusively indicative character, since each region has its own specificity not only by purely natural factors, but also by all internal systems. That is why signs of semi-desert properties and weak self-healing ability are noted in all score maps. Based on these considerations, these loads are considered as a first approximation. And one more important point: since we received the partial environmental assessments in a generalized form (weighted average impact score), here we will also have a generalized integral assessment, i.e. in fact, (8) and (9) are also not equations, but formula Certainly, a real test of the justification of the importance of intra-system connections would be to build a dynamic model of an oriented weighted graph with a delay of the natural system of the Mangystau region with four vertices, because relationships equations in such a graph are a difference scheme of a system of interconnected differential equations describing a complex dynamic system of the natural environment. However, to determine the methods of transition to various differential equations. Even graph models are rarely used because their construction requires a large amount of operational information on all components of the natural environment.

Since we solve the inverse problem under the condition of a "ready-made" comprehendsive environmental assessment, we can hardly expect that such a huge amount of work as the release of the Atlas of the Mangystau region will be carried out regularly. Therefore, we will "subjectively" choose sets of weight loads from "subjective" justifications. As the above review of sources showed, the possibility of choosing from expert estimates is small - either equivalent relationships, or estimates selected as a first approximation with a slight advantage of the role of vegetation.

The final result of the generalized solution of the inverse problem of the integrated environmental assessment (the definition of the contribution of the OGPC to the formation of the general ecological situation) of the Mangystau region is still determined by subtracting the value from $I O F_{R e g}$. from the value of $I O F_{O G P C}$.

$$
I S I P=I O F_{O G P C}-I O F_{R e g}
$$

The immediate goal of this work according to the first method is achieved by comparing the options for solving equations (8), (9) with other sets of loads in equations (5), (6).

In order to exclude the possibility of fitting integral solutions by the advantageous selection of loads on the components of the natural environment in integral target functions and the final solution of the inverse problem by a generalized method, we will check these solutions on other sets of these loads. In the first case, we check by comparing the results of the calculations that we adopted (also subjectively) proposed in the literature of another set of subjective assessments of components of the environment.

As the second option of the calculation experiment according to the first method, we take the option of equivalent loads, which is often found in literary sources. To enable the comparison of the values of the target functions obtained in the experiment and the results of solving the inverse problem, we again take the sum of all the loads for 1 , then all the loads will be equal to 0.25 , i.e. in the second version of the calculations, all the loads in equations (8) and (9) will be equal to 0.25 .

As a third option of the first method for assessing accuracy, we will conduct another experiment with an attempt to objectify the justification of a set of loads. Now we will justify this set not by references to literary sources, but by calculating the normalized values of particular target functions that characterize the weighted average level of anthropogenic impact on each component of the natural environment.

Because the private objective functions for the overall assessment of the transformation of the $j$-th component of the natural environment $\left(C N E_{j}\right)$ in the region $\left(P O F_{C N E j R e g}\right)$ and for the zones with OGPC are different, we will normalize the loads separately by determining the fraction of the value of the private target function of the sum of their 
values for all components for the whole region and for areas with OGPC.

The actual source material for the option calculations of the integrated generalized estimation by the first method is the performed results of the calculations of generalized quotients objective (4) - (5) and private target functions (8) - (9) for loads considered as a first approximation, as well as results of generalized private and integral solving the inverse problem of a comprehensive environmental assessment (Table 1).

Table 1 - Initial data for assessing the accuracy and objectivity of solving the inverse problem of a comprehensive environmental assessment by the generalized method with the loads on private target functions considered as a first approximation

\begin{tabular}{|c|c|}
\hline $\begin{array}{l}\text { Type of functions obtained by the method of generalized assessment of the contribution of the } \\
\text { OGPC to the formation of the environmental situation in the Mangystau region }\end{array}$ & $\begin{array}{l}\text { The results of calculations for } \\
\text { the initial version of the load }\end{array}$ \\
\hline \multicolumn{2}{|l|}{ For relief } \\
\hline $\begin{array}{l}P O F_{\text {relReg }} \text { - Private target function (averaged estimation of anthropogenic impact) for relief } \\
\text { over the territory of the region, point }\end{array}$ & 4,039 \\
\hline $\begin{array}{l}P O F_{\text {relOGPC }} \text { - Private target function (averaged estimation of anthropogenic impact) for relief in } \\
\text { zones with OGPC, point }\end{array}$ & 5,712 \\
\hline $\begin{array}{l}\text { PSIPrel-The solution of the inverse inverse problem for the relief (additional contribution of } \\
\text { the OGPC to the anthropogenic disturbance of the relief in the zones with OGPC as compared } \\
\text { to the weighted average over the territory of the Mangystau region) }\end{array}$ & 1,67 \\
\hline \multicolumn{2}{|l|}{ For soil } \\
\hline $\begin{array}{l}P O F_{\text {soil }} \text { Reg - Private target function (averaged estimation of anthropogenic impact) for soils } \\
\text { over the territory of the region, point }\end{array}$ & 2,375 \\
\hline $\begin{array}{l}P O F_{\text {soil }} O G P C-\text { Private target function for soils (averaged estimation of anthropogenic impact) } \\
\text { for soils in zones with OGPC, point }\end{array}$ & 4,021 \\
\hline $\begin{array}{l}P S I P_{\text {soil }} \text { - The solution of a particular inverse problem for soils (an additional contribution of the } \\
\text { OGPC to the anthropogenic disturbance of soils in the zones with OGPC in comparison with } \\
\text { the weighted average over the territory of the Mangystau region), a score }\end{array}$ & 1,65 \\
\hline \multicolumn{2}{|l|}{ For vegetation } \\
\hline $\begin{array}{l}P O F_{V e g R e g}-\text { Private target function (averaged estimation of anthropogenic impact) for } \\
\text { vegetation in the territory of the region, point }\end{array}$ & 3,670 \\
\hline $\begin{array}{l}P O F_{V e g O G P C}-\text { Private objective function (averaged estimation of anthropogenic impact) for } \\
\text { vegetation in zones with OGPC points }\end{array}$ & 6,849 \\
\hline $\begin{array}{l}P S I P_{\text {veg. }}-\text { Solution of the inverse problem for vegetation (additional contribution of OGPC to } \\
\text { anthropogenic disturbance of vegetation in zones with OGPC as compared to weighted average } \\
\text { in Mangystau region), score }\end{array}$ & 3,18 \\
\hline \multicolumn{2}{|l|}{ For groundwater } \\
\hline $\begin{array}{l}P O F_{G W R e g}-\text { Private target function (averaged estimation of anthropogenic impact) for } \\
\text { groundwater in the territory of the region, point }\end{array}$ & 5,509 \\
\hline $\begin{array}{l}P O F_{G W O G P C} \text { - Private objective function (averaged estimation of anthropogenic impact) for } \\
\text { groundwater in zones with OGPC, point }\end{array}$ & 7,964 \\
\hline $\begin{array}{l}P S I P_{G W} \text { - solution a particular inverse problem for groundwater (an additional contribution of } \\
\text { OGPC to anthropogenic disturbance of groundwater in zones with OGPC as compared to the } \\
\text { average weighted in the Mangystau region), a score }\end{array}$ & 2,46 \\
\hline \multicolumn{2}{|c|}{ The results of solving the inverse problem of integrated environmental assessment for all components of the natural environment } \\
\hline $\begin{array}{l}I O F_{R e g}-\text { Integral objective function of anthropogenic disturbance of the natural environment of } \\
\text { Mangystau region, point }\end{array}$ & 4,22 \\
\hline $\begin{array}{l}I O F_{O G P C} \text { - Integral target function of anthropogenic disturbance of the natural environment of } \\
\text { the Mangystau region within the zones with OGPC, point }\end{array}$ & 6,48 \\
\hline $\begin{array}{l}\text { ISIP - Generalized solution of the inverse problem (additional contribution of the OGPC to the } \\
\text { anthropogenic disturbance of the natural environment in the zones with OGPC in comparison } \\
\text { with the average weighted in Mangystau region), point }\end{array}$ & 2,26 \\
\hline
\end{tabular}


The second way to check the accuracy of the generalized method for solving the inverse problem is in changing the composition of the original cartographic material. To simplify the verification, we will carry out an experimental calculation of the integral solution of the inverse problem with a smaller amount of the initial cartographic material. For this, in the initial set of four assessment maps, instead of the Anthropogenic Transformation of Vegetation and Soil Degradation maps, we take a map of the impact of the oil and gas complex from the soil and plant layer. There is no such separate map in the Atlas of the Mangistau Region; for its construction, the contours of 5 levels of the ecological state of the soil and plant layer from the published map "The Impact of the Oil and Gas Complex on Natural and Economic Systems" were taken from (Atlas :2011) (Figure 2). For remaining components of the natural environment (relief and groundwater) we use ready-made maps private generalized solutions from table 1 .

The choice of this map for experimental calculations is due to the generality of the information base used by the Institute of Geography to make all estimated expert maps, the objectivity of which is already verified in a large list of impact factors in the previous sections.

From the new map data for the second method checking the accuracy of solving the inverse problem of a comprehensive environmental assessment with a reduced set of initial assessment map is shown in Table 2. Here are the total contour areas of each five levels of anthropogenic impact throughout the region and for zones with OGPC, the corresponding values of the functions of i-th level of anthropogenic disturbance of soil and plant layer ( $f_{\text {iSVLReg }}$ and

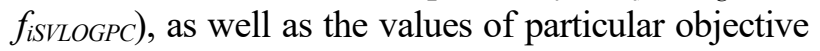
functions and a particular solution of the inverse problem for the soil-plant layer.

The second methods of combination of the initial data of Table 1 on relief and groundwater and the data of Table 2 according to the $P O F_{S V L R e g}$ and $P O F_{S V L R e g}$ OGPC fully provides an estimate of the accuracy of the generalized model.

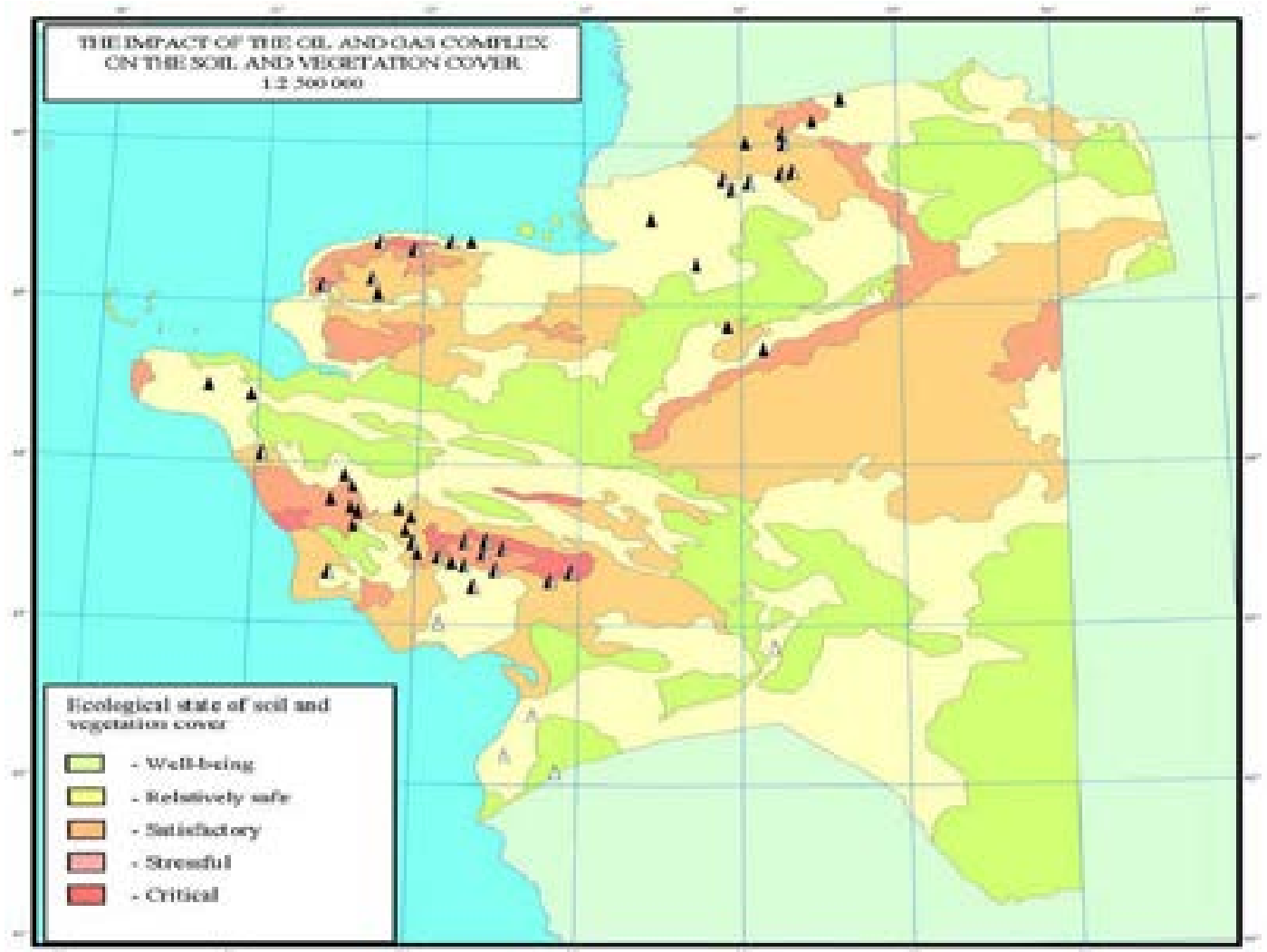

Figure 2 - Map of anthropogenic impact on the soil-vegetation layer (based on the map "The impact of the oil and gas complex on natural-economic systems" of (Atlas: 2011 ) 
Table 2 - Initial data on the soil-vegetation layer for the implementation of the second method for assessing the accuracy and objectivity of s olving the inverse problem of integrated environmental assessment by a generalized method

\begin{tabular}{|c|c|c|c|c|c|c|}
\hline \multirow[b]{2}{*}{ Type of function and unit of measure } & \multicolumn{5}{|c|}{ Degree of anthropogenic transformation } & \multirow[b]{2}{*}{ Total } \\
\hline & \begin{tabular}{|c|} 
Inconsi- \\
derableor no
\end{tabular} & Weak & Moderate & $\begin{array}{l}\text { Consi- } \\
\text { derable }\end{array}$ & Significant & \\
\hline \multicolumn{7}{|l|}{\begin{tabular}{|l|} 
For the soil-plant layer \\
\end{tabular}} \\
\hline $\begin{array}{l}\text { Total area of contours of the } \mathrm{i} \text {-th level of } \\
\text { anthropogenic disturbance, } \mathrm{km} 2\end{array}$ & 45641,44 & 67068,46 & 41649,56 & 9997,87 & 1632,16 & 165989,49 \\
\hline $\begin{array}{l}F_{\text {SVLReg } i}-\text { ratio of the sum of the areas of the contours } \\
\text { of the i-th level of transformation to the area of the } \\
\text { domain, the dimensionless quantity }\end{array}$ & 0,275 & 0,404 & 0,251 & 0,060 & 0,010 & \\
\hline \multicolumn{6}{|c|}{$P O F_{S V L R e g}-$ private objective function for the soil-vegetation layer over the territory of the region, point } & 3,252 \\
\hline $\begin{array}{l}\text { Total area of contours of the i-th level of } \\
\text { transformation within the zones with OGPC, km2 }\end{array}$ & 192,16 & 1282,98 & 2322,62 & 1638,46 & 1572,14 & 7008,35 \\
\hline $\begin{array}{l}F_{S V L O G P C i}-\text { ratio of the sum of the areas of the contours } \\
\text { of the i-th level of transformation within the zones } \\
\text { with OGPC to the area of all zones with OGPC, the } \\
\text { dimensionless value }\end{array}$ & 0,027 & 0,183 & 0,331 & 0,234 & 0,224 & \\
\hline \multicolumn{6}{|c|}{$P O F_{S V L O G P C}-$ private objective function for the soil-vegetation layer for zones with OGPC, a score } & 5,89 \\
\hline \multicolumn{6}{|c|}{$\begin{array}{l}P S I P_{S V L}-\text { Solving a particular inverse problem (an additional contribution of the OGPC to the anthropogenic } \\
\text { disturbance of the soil and vegetation layer in the Mangystau region), a score }\end{array}$} & 2,64 \\
\hline
\end{tabular}

The method for obtaining private target functions and a particular solution to the inverse problem of a comprehensive environmental assessment, described in general terms by equations (3) - (5), is also used for the soil and plant layer (see Table 2). But for integral objective functions, it is necessary to take into account that in the equations of integral estimates of anthropogenic impact for the territory of the entire region and for zones with OGPC (equations (6) and (7)) there will be not four, but three terms, so the load distribution in the integral objective functions is necessary justify again.

Again we refer to literary sources, the analysis of which was carried out in the methodological section. We proceed from the idea of close intrasystemic relationships in natural systems and visualization of the natural system in the form of a graph with four angles for a system of four components and a triangle of three. In a rectangle, vertex relationships can be represented by sides and diagonals. Diagonal ties may differ from ties on the sides - the length of the diagonal is longer than the length of the sides. And in the triangle, all the vertices are connected only by the sides, so with three components it is difficult to distinguish the prevailing connection. Let us take them as a first approximation. Then, subject to the normalization of the sum of the loads per unit, we obtain two loads of 0.33 each and one -0.34 . Since in the set of four components we preferred the load on the vegetation, and now we assign the load value of 0.34 to the soil and plant layer. Then the equations for the integral target functions and the integral generalized solution of the inverse problem can be written as:

$$
\begin{gathered}
I O F_{\text {Reg }}=0,33 P O F_{\text {relReg }}+0,34 P O F_{S V L R e g}+ \\
+0,33 P O F_{G W R e g} \\
I O F_{O G P C}=0,33 P O F_{\text {relOGPC }}+ \\
+0,34 P O F_{S V L O G P C}+0,33 P O F_{G W O G P C} \\
I D I P=I O F_{O G P C}-I O F_{\text {Reg }}
\end{gathered}
$$

The results of solving equations (11) - (13) are shown in Table 3. These results are the initial data for assessing the accuracy of solving the inverse problem of a comprehensive environmental assessment by the generalized method using a reduced set of initial assessment maps. 
Table 3 - Initial data for the implementation of the second method for assessing the accuracy and objectivity of solution of the inverse problem of integrated environmental assessment by the generalized method

\begin{tabular}{|c|c|}
\hline Type of function and unit of measure & $\begin{array}{l}\text { Value of the } \\
\text { function }\end{array}$ \\
\hline$P O F_{\text {relReg }}$ - private target function for the relief over the territory of the region, point & 4,039 \\
\hline$P O F_{\text {RelOGPC }}$ - private target function for the relief by zones with OGPC, point & 5,712 \\
\hline$P O F_{\text {SVLReg }}$ - private target function for the soil-vegetation layer over the territory of the region, point & 3,252 \\
\hline POF $S V L O G P C$ - private target function for the soil-vegetative layer for zones with OGPC, a score & 5,89 \\
\hline$P O F_{G W R e g}$ - private target function for groundwater over the territory of the region, point & 5,508 \\
\hline$P O F_{G W} O G P C-$ private target function for groundwater in zones with OGPC, point & 7,964 \\
\hline \multicolumn{2}{|c|}{ The results of solving the inverse problem of integrated environmental assessment for all components of the natural environmen } \\
\hline $\begin{array}{l}I O F_{\text {Reg. }} \text { - Integral target function of anthropogenic disturbance of the natural environment of Mangystau } \\
\text { region, point }\end{array}$ & 4,26 \\
\hline $\begin{array}{l}I O F_{O G P C} \text { - Integral target function of anthropogenic disturbance of the natural environment of the } \\
\text { Mangystau region within the zones with OGPC, point }\end{array}$ & 6,52 \\
\hline $\begin{array}{l}I S I P \text { - generalized solution of the inverse problem (an additional contribution of the OGPC to the } \\
\text { anthropogenic disturbance of the natural environment of the Mangystau region), a score }\end{array}$ & 2,26 \\
\hline $\begin{array}{l}\text { ISIP - generalized solution of the inverse problem (additional contribution of the OGPC to the } \\
\text { anthropogenic disturbance of the natural environment of the Mangystau region), } \%\end{array}$ & 22,59 \\
\hline
\end{tabular}

\section{Results and Discussion}

The aim of this work is provided assessing the accuracy of the method proposed by the authors for the generalized solution of the inverse problem of integrated environmental assessment of the territory in two ways - 1) by comparing the solution results for different types of expert sets of loads (roles) of the components of the environment in integrated environmental assessments in the form of objective functions to identify the impact of their possible subjectivity and 2) on the various composition of the source cartographic material with options for sets of loads on the objective functions.

Design experiments with different sets of weight loads according to the second embodyment of the first method will not be a problem, because these loads are involved only in the final stage of solving the inverse problem. When calculating the generalized integral objective functions with the change in the values of the weight loads to the same for all components of the environment, we use equations (6) and (7), in which all aij $=0.25$. Equation (10) will not change its form.
For implementation of the third option of the first method for assessing accuracy, it is necessary to justify a set of loads by calculating the normalized values of particular objecttive functions that characterize the weighted average level of anthropogenic impact on each component of the natural environment. Since the private objective functions for the total estimation of the transformation of the $\mathrm{j}$-th component of natural environment $(\mathrm{CNErj})$ by the region ( $\left.P O F_{C N E j R e g}\right)$ and for the zones with OGPC differ, the loads will be normalized separately by determining the fraction of the value of the particular objective function from the sum of their values over all components for the whole region and for the zones with OGPC. The results of load calculations are given in Table 4.

In this case, the equation for calculating integral functions takes the following form:

$$
\begin{aligned}
& I O F_{\text {Reg }}=0,2591 P_{\text {OF }} F_{\text {RelReg }}+0,152 P O F_{\text {SoilReg }}+ \\
& \quad+0,2255 P O F_{\text {VegReg }}+0,3534 P O F_{G W R e g}
\end{aligned}
$$

$$
\begin{aligned}
& \text { IOF }_{O F P C}=0,2327 P O F_{\text {RelOGPC }}+0,164 P O F_{\text {Soil OGPC }}+ \\
& \quad+0,279 P O F_{\text {VegOGPC }}+0,3244 P O F_{G W O G P C}
\end{aligned}
$$


L.M. Pavlichenko et al.

Table 4 - Results of calculations of normalized loads on the components of natural environment from the values private objective functions

\begin{tabular}{|c|c|c|c|c|}
\hline \multirow{2}{*}{$\begin{array}{c}\text { The components of the } \\
\text { natural environment }\end{array}$} & \multicolumn{2}{|c|}{ The values of the private target functions } & \multicolumn{2}{c|}{ The values of the normalized weights } \\
\cline { 2 - 5 } & $P O F_{C N E j R e g}$ & $P O F_{C N E p j O G P C}$ & $P_{C F_{C N E p j R e g}}$ & $P_{\text {ONEPOGPC }}$ \\
\hline Relief & 4,0388 & 5,712 & 0,2591 & 0,2327 \\
\hline Soil & 2,3696 & 4,022 & 0,1520 & 0,1638 \\
\hline vegetation & 3,67 & 6,8493 & 0,2355 & 0,2790 \\
\hline groundwater & 5,508 & 7,9645 & 0,3534 & 0,3244 \\
\hline The total value & 15,5864 & 24,5478 & & \\
\hline
\end{tabular}

A comparison of the results of calculations for all options of the choice of weight loads in generalized integral objective functions and the corresponding generalized solutions of the inverse problem presented in Table 5 .

As can be seen from table 5, both versions of the sets of loads on the components of the environment according to literary sources give almost the same results - the difference in the obtained values of the functions does not exceed $0.22 \%$. Taking into account the specifics of the territories according to the intensity of anthropogenic impact when calculating the loads by private target functions only a small increase in the values of the integrated target values was (about 4\%) and practically did not affect the generalized solution of the inverse problem, decreasing the value by less than $0.5 \%$.

Table 5 - Comparison of the results of solving the inverse problem of a comprehensive environmental assessment for all components of the environment for different sets of loads on the components of the environment according to the first method

\begin{tabular}{|c|c|c|c|}
\hline \multirow{3}{*}{ Type of function and unit of measure } & \multicolumn{3}{|c|}{$\begin{array}{l}\text { The results of calculations of integral objective functions and solution } \\
\text { of the inverse problem for options of the choice of loads for the } \\
\text { components of the natural environment }\end{array}$} \\
\hline & \multicolumn{2}{|c|}{ According to published sources } & \multirow{2}{*}{$\begin{array}{l}\text { On the basis of private } \\
\text { objective functions }\end{array}$} \\
\hline & $\begin{array}{l}\text { Regulating role of } \\
\text { vegetation }\end{array}$ & $\begin{array}{l}\text { equivalent } \\
\text { connection }\end{array}$ & \\
\hline $\begin{array}{l}I O F_{R E G} \text { - integral target function anthropogenic } \\
\text { disturbance of the natural environment of Mangystau } \\
\text { region, the score }\end{array}$ & 3,89 & 3,9 & 4,22 \\
\hline $\begin{array}{l}\text { IOF } O G P C \text { - Integral target function of anthropogenic } \\
\text { disturbance of the natural environment of the Mangystau } \\
\text { region within the zones with OGPC, point }\end{array}$ & 6,17 & 6,17 & 6,48 \\
\hline $\begin{array}{l}\text { ISIP - A generalized solution of the inverse problem (an } \\
\text { additional contribution of the OGPC to the } \\
\text { anthropogenic disturbance of the natural environment of } \\
\text { the Mangystau region), a score }\end{array}$ & 2,28 & 2,27 & 2,27 \\
\hline
\end{tabular}

The second method for assessing the accuracy of the method proposed by the authors of a generalized solution of the inverse problem of a comprehensive environmental assessment of the territory - according to different composition of the original cartographic material. Since it is not possible to implement the option of equivalent loads on the components of the environment in the case of three initial estimated maps, we will also consider the option of assessments for the second method according to the normalized values of the private target functions for the relief, soil and plant layer and groundwater. 
Table 6 - Results of calculations of normalized loads on the components of the natural environment from the values of private objective functions with a changed set of initial evaluation maps

\begin{tabular}{|l|c|c|c|c|}
\hline \multirow{2}{*}{ The components of the natural environment } & \multicolumn{2}{|c|}{$\begin{array}{c}\text { The values of the private objective } \\
\text { functions }\end{array}$} & \multicolumn{2}{c|}{ The values of the normalized weights } \\
\cline { 2 - 5 } & $P O F_{C N E p j R e g}$ & $P O F_{C N E P j O G P C}$ & $P_{\text {OF }}$ CNEjReg & $P_{\text {OOF }}$ CNEjOGPC \\
\hline The relief & 4,039 & 5,712 & 0,316 & 0,233 \\
\hline The soil-plant layer & 3,252 & 5,889 & 0,254 & 0,164 \\
\hline The groundwater & 5,508 & 7,964 & 0,430 & 0,324 \\
\hline The total value & 12,800 & 19,566 & & \\
\hline
\end{tabular}

In this case, the equation for calculating integral functions takes the following form:

$$
\begin{gathered}
I O F_{\text {Reg }}=0,316 P O F_{\text {RelReg }}+0,254 P O F_{\text {SVLReg }}+ \\
+0,430 P O F_{\text {SVReg }} \\
I O F_{\text {OGPC }}=0,233 P O F_{\text {relOGPC }}+0,164 P O F_{\text {SVOGPC }}+ \\
+0,324 P O F_{\text {GWOGPC }}
\end{gathered}
$$

A comparison of the accuracy and objectivity of the calculation results for all options for the selection of weight loads in the generalized integral target functions and the corresponding generalized solutions of the inverse problem for the two estimation methods presented in table 7. As can be seen from table 7, the result of a generalized solution of the integral inverse problem of the ISIP (the additional contribution of the oil and gas complex to the anthropogenic change in the environmental situation in the zones with their development in the Mangistau region on the basis of three initial maps was $22.4 \%$ against $22.8 \%$ when assessed using four a set of loads, taking into account the regulatory role of vegetation. Thus, the difference in assessments of the contribution of OGPC to the formation of the environmental situation was 0.04 points, or $0.4 \%-\mathrm{a}$ very good coincidence. When choosing the loads on the components of the natural environments on the basis of normalized partial objective functions ISIP was $22.1 \%$ for the three initial maps against $22.6 \%$ in four, ie in this case it turned out very good

\begin{tabular}{|c|c|c|c|c|}
\hline \multirow{3}{*}{ Type of function and unit of measure } & \multicolumn{4}{|c|}{$\begin{array}{c}\text { Options of the choice of loads for the components of the natural } \\
\text { environment }\end{array}$} \\
\hline & \multicolumn{2}{|c|}{$\begin{array}{c}\text { Accounting for the regulatory role of } \\
\text { vegetation for evaluation maps in } \\
\text { quantity }\end{array}$} & \multicolumn{2}{|c|}{$\begin{array}{l}\text { On the basis of private objective } \\
\text { functions for evaluation maps } \\
\text { in quantity }\end{array}$} \\
\hline & 4 & 3 & 4 & 3 \\
\hline $\begin{array}{l}I O F_{\text {Reg.- integral target function anthropogenic }} \\
\text { disturbance of the natural environment of } \\
\text { Mangystau region, the score }\end{array}$ & 3,89 & 4,28 & 4,22 & 4,47 \\
\hline $\begin{array}{l}\text { IOF } O G P C \text { - Integral target function of } \\
\text { anthropogenic disturbance of the natural } \\
\text { environment of the Mangystau region within the } \\
\text { zones with OGPC, point }\end{array}$ & 6,17 & 6,52 & 6,48 & 6,68 \\
\hline $\begin{array}{l}\text { ISIP-A generalized solution of the inverse } \\
\text { problem (an additional contribution of the OGPC } \\
\text { to the anthropogenic disturbance of the natural } \\
\text { environment of the Mangystau region), a score }\end{array}$ & 2,28 & 2,24 & 2,26 & 2,21 \\
\hline
\end{tabular}
agreement.

Table 7 - Comparison of the results of solving the inverse problem of integrated environmental assessment for different sets of evaluation maps and for different sets of loads on the components of the natural environment in the first and second methods 
Thus, the proposed method for the generalized solution of the inverse problem of a comprehensive ecological assessment of the territory practically does not respond to changes in the loads on the components of the environment both with four initial assessment maps, since this influence is leveled by the procedure of subtracting integral target function throughout the territory from its analogue for zones with OGPC.

The results obtained for all experimental sets of loads and with a change in the set of initial assessment maps indicate a significant impact of OGPC on the environmental situation in areas.

\section{Conclusions}

The article demonstrates specific results of assessing the accuracy and objectivity of solving a new theoretical problem in the field of integrated environmental assessments. It is shown that the new types of assessments obtained have a fairly high degree of reliability and therefore make it possible to objectify the assessment of the additional contribution of an individual industry to the total ecological situation of the territory

Comparison of the results of experimental calculations for equivalent loads with the set adopted as the initial set with an increase in the effect of vegetation shows that the values of generalized integral solutions of the inverse problem obtained for equivalent weight loads differ by 0.01 points, or $0.08 \%$. In the values of the integral objective functions, differences by 0.01 points were obtained only for the entire territory of the region, and for zones with OGPC the solutions completely coincided.

The results of load normalization by private target functions demonstrate the influence of anthropogenic impact on the assessment of the strength of intra-systemic relationships, and not only the size of the bonds changes - the nature of their distribution also changes: in areas with OGPC, the effect on soils and vegetation increased compared to the average for the region, but decreased on the relief and groundwater.

The results of solving the inverse problem showed a decrease in the value of ISIP from 2.43 to 2.27 points (by 0.16 ) when replacing the loads according to literary estimates with loads normalized for private objective functions. At the same time, the value of ISIP practically coincided with its value in three components -2.27 and 2.26.
Thus, the proposed method for the generalized solution of the inverse problem of a comprehensive ecological assessment of the territory practically does not respond to changes in the loads on the components of the environment, since this influence is leveled by the procedure of subtracting the integral objective function throughout the territory from its analogue for zones with oil and gas producing complex.

For the experimental calculation of ISIP by the second method, the amount of the initial cartographic material was reduced: in the problem of three components, instead of the Anthropogenic Transformation of Vegetation and Soil Degradation maps, we took a map of the effect of the oil and gas producing complex on the soil and plant layer.

The result of a generalized solution of the integral inverse problem of the ISIP (additional contribution of the oil and gas producing complex to the anthropogenic change in the environmental situation in areas with their development in the Mangistau region according to three initial maps, it was $22.4 \%$ against $22.8 \%$ when assessed by four when recruiting loads, taking into account the regulatory role of vegetation. Thus, the difference in assessments of the contribution of OGPCs to the formation of the environmental situation was 0.04 points, or $0.4 \%$ - a very good coincidence. When choosing the loads on the components of the environment on the basis of normalized private target functions, the ISIP amounted to $22.1 \%$ for three initial maps against $22.6 \%$ for four, i.e. and in this case a very good coincidence was obtained.

The reasons for a good coincidence can be taken from a single source of maps, built on a uniform methodology and a single extensive database, allowing for expert generalizations to use a huge amount of diverse information on a large number of impact factors on each initial assessment map.

Therefore, the accuracy and objectivity of the "finished" direct problem - the integrated environmental assessment on the maps we took as the basis of the initial data - is the key to a sufficient accuracy of solving the inverse problem of an integrated environmental assessment. The intra-systemic relationships between the components of the natural environment automatically taken into account in each assessment maps, since each of them takes into account all the information available to form the idea and content of these expert maps. This is explained by the fact that each assessment maps is 
an expert generalization of the actual material obtained on the basis of data from the monitoring network, expeditionary environmental and inventory studies, and remote sensing data, and therefore it demonstrates a huge list of factors affecting each component of the natural environment

In other words, whatever map we consider from this single complex of evaluation maps, they all will have a high degree of objectivity, which determines the accuracy of the solution of the inverse problem on these maps. The work is one of the results of the grant project of the Ministry of Education and Science of the Republic of Kazakhstan No. 0589 / GF-4 Development of a method for objectifying expert assessments of the contribution of individual pollution sources to the general environmental situation of the territory.

\section{References}

Atayev Z.V. (2014) Morphometriyy reliefa kak factor formarofaniya i prostranstvennoi differenziazii nizkogorno-predgornyh landshaftov Severo-Vostochnogo Kavkaza. [Morphometry of the relief as a factor of formation and spatial differentiation of lowmountain foothill landscapes of the North-Eastern Caucasus] - Molodoi uchenyi.- Pp. 400-407 (In Russian)

Aliyev S.A. (1978) Ekologiya i energetika biokhimicheskikh protsessov prevrashcheniya organicheskogo veshchestva pochv. [Ecology and power engineering of biochemical processes of transformation of soil organic matter]- Baku: ELM. - P. 120. (In Russian)

Aleksandrova L.N. (1987) Organicheskoye veshchestvo pochvy i protsessy yego transformatsii. [Organic matter of the soil and the processes of its transformation]- L.: Nauka. - P.340. (In Russian)

Armand A.D. (1992) Mekhanizmy ustoychivosti geosistem. [Mechanisms of stability of geosystems]- M.: Nauka. - P. 208. (In Russian)

Atlas Mangistauskoy oblasti [Atlas of the Mangystau region](2011) / Pod red. A.R. Medeu. Almaty. - P. 1. (In Russian)

Avessalomova I.A. (1992) Ekologicheskaya otsenka landshaftov. [Ecological assessment of landscapes]- M.: Izd-vo MGU. P. 88. (In Russian)

Alekin O.A. (1948) Obshchaya gidrokhimiya. [General hydrochemistry]- L.: Izd-vo LGU. - P. 186. (In Russian)

Armand D.L. (1975) Nauka o landshafte. [Mechanisms of stability of geosystems] - M.: Mysl'. - Pp. 288. (In Russian)

Burakov M.M. Sootnosheniye model'nykh predstavleniy o dvizhenii podzemnykh vod, yego teoreticheskiye i prakticheskiye prilozheniya. [The correlation of model concepts of groundwater movement, its theoretical and practical applications] // Geol. Kaz. - 2002. - № 4. - P. 72-86. (In Russian)

Burakov M.M., Veselov V.V., Pavlichenko L.M. (2000) Sovremennyye problemy gidrogeologicheskogo rayonirovaniya i vozmozhnyye puti ikh preodoleniya [Modern problems of hydrogeological zoning and possible ways to overcome them]// Vest. KazGU. Ser. geogr. - № 2 (11). - Pp. 71-91. (In Russian)

Chigarkin A.V. (1995) Geoekologiya Kazakhstana: Uchebnoye posobiye. [Geoecology of Kazakhstan: Textbook] - Almaty: Sanat. - P. 160. (In Russian)

Chepurnykh N.V., Novoselov A.L. (1995) Planirovaniye i prognozirovaniye prirodopol'zovaniya: Uchebnoye posobiye. [Planning and forecasting of nature use: Textbook] - M.: Interpraks. - P. 288. (In Russian)

Dostay ZH.D. (1999) Nauchnyye i prikladnyye osnovy upravleniya gidroekologicheskim sostoyaniyem besstochnykh basseynov Tsentral'noy Azii (na primere bayeyna oz. Balkhash): Dis.... d-ra geogr. nauk [Scientific and applied fundamentals of the management of the hydroecological state of the drainage basins of Central Asia (on the example of the Baykh of Lake Balkhash): Dis .... Dr. geogr. Sciences]- Almaty. - P.305. (In Russian)

Dokuchayev V.V. (1949) Izbrannyye sochineniya. V 3-kh tomakh. [Selected works. In 3 volumes]- M.: Gosudarstvennoye izdatel'stvo sel'skokhozyaystvennoy literatury. - P. 240. (In Russian)

Ekoinformatika: Teoriya. Praktika. Metody i sistemy (1992) [Ecoinformatics: Theory. Practice. Methods and systems]/ Pod red. V.Ye. Sokolova. - SPb.: Gidrometeoizdat. - P. 495. (In Russian)

Gel'dyyeva G.V., Plokhikh R.V. (2003) Landshaftnaya karta kak osnova geografo-indikatsionnykh issledovaniy (na primere Shortandinskogo rayona Akmolinskoy oblasti) // Gidrometeorologiya i ekologiya. [Landscape map as a basis for geographic and indicator studies (on the example of the Shortandinsky district of the Akmola region)]-№1. - Pp. 146-155. (In Russian)

Gmoshinskiy V.G. (1977) Inzhenernaya ekologiya. [Engineering ecology]- M.: Znaniye. - P. 64. (In Russian)

Imanbayeva A.A., Sagyndykova M.S. (2009) Monitoring sostoyaniya rastitel'nosti na neftegazovom mestorozhdenii Karazhanbas. [Monitoring of the state of vegetation at the Karazhanbas oil and gas field]- Vestnik KazNU. Seriya ekologicheskaya. - № 1 (24) - Pp. 71-75. (In Russian)

Dzheffers Dzh. (1981) Vvedeniye v sistemnyy analiz: primeneniye v ekologii. [Introduction to system analysis: application in the Environment]- M.: Mir. - P. 213. (In Russian)

Kovda V.A. (1973) Osnovy ucheniya o pochvakh. [Fundamentals of the doctrine of soils] - M.: Nauka. - T. 1-2. - P. 340. (In Russian)

Luk'yanchikov N.N., Potravnyy I.M. (2010) Ekonomika i organizatsiya prirodopol'zovaniya: Uchebnoye posobiye: rek. Min. RF - 4-ye izd., Pererab. i dop. [Economics and organization of nature management: Textbook: рек. Min. RF - 4 th ed., Pererab. And additional.] - M.: Yedinstvo-dana. - P. 688. (In Russian)

Mil'kov F.N. (1990) Obshcheye zemlevedeniye: Ucheb. dlya stud. geograf. spets. vuzov. [General Geography: Proc. For stud. Geographer. Specialist. Universities]- M.: Vyssh. shk.. - P. 335. (In Russian) 
Mukhina L.I. (1973) Printsipy i metody tekhnologicheskoy otsenki prirodnykh kompleksov. [Principles and methods of technological evaluation of natural complexes]- M.: Nauka. - P.94. (In Russian)

Pentl R. (1979) Metody sistemnogo analiza okruzhayushchey sredy. [Methods of system analysis of the environment] - M.: Mir. - P. 215. (In Russian)

Pavlichenko L.M., Baymuratova D.I, Yespolayeva A.R. (2015) Otsenka vliyaniya neftegazodobyvayushchego kompleksa Mangistauskoy oblasti na antropogennuyu modifikatsiyu rel'yefa [Assessment of the impact of the oil and gas producing complex of the Mangystau region on the anthropogenic modification of the relief]// «Neft' i gaz» (RK). - №4 (88). - Pp. 133-141. (In Russian)

Pavlichenko L.M., Yespolayeva A.R. (2014) Problemy ob"yektivizatsii kompleksnoy ekologicheskoy otsenki geoekosistem [Problems of the objectification of the integrated environmental assessment of geoecosystems]// «Vestnik KazNU. Seriya geograficheskaya» (vypusk po materialam Mezhdunarodnoy nauchnoy konferentsii, posvyashchennoy 75-letiyu professora, d.g.n. V.S. Cherednichenko. «Sovremennye Problemy Gidrometeorologii i Geoecologii». - №. 1 (40). - Pp. 283-289. (In Russian)

Pavlichenko L.M., Yespolayeva A.R., Iztayeva A.M. (2016) Soderzhaniye tyazhelykh metallov v pochve Mangistauskoy oblasti [The content of heavy metals in the soil of the Mangystau region]// Sb.st. po materialam XL mezhdunar. nauch.-prakt. konf. «Yestestvennyye i matematicheskiye nauki v sovremennom mire»- Novosibirsk: Izd. ANS «SibAK». -№3 (38). - Pp. 114-123. (In Russian)

Pavlichenko JI. M., Yespolayeva A. P., Iztayeva A. (2016) Vliyaniye neftyanogo zagryazneniya na formirovaniye rastitel'nogo pokrova Mangistauskoy oblasti [The impact of oil pollution on the formation of vegetation of Mangystau region]// International Scientific Review № 3 (13) / XI International Science Conference (New York. USA, 7- 8 March, 2016). - Pp. 25-32. (In Russian)

Pavlichenko L.M. (2000) Sistemnoye modelirovaniye prirodno-tekhnicheskikh geosistem [System modeling of naturaltechnical geosystems]// Novyye podkhody i metody v izuchenii prirodnykh i prirodno-khozyaystvennykh sistem, Almaty, 2000. Almaty: Kazak universiteti. - Pp. 132-135. (In Russian)

Pavlichenko L.M. (2000) Vyyavleniye i rayonirovaniye rezhimoobrazuyushchikh faktorov ekogeosistem sovremennoy del'ty r. Ili [Identification and regionalization of the regime-forming factors of the ecogeosystems of the present delta of the river Ili]// Tezisy dokladov Mezhdunarodnogo ekologicheskogo foruma po problemam ustoychivogo razvitiya Ili-Balkhashskogo basseyna "Balkhash-2000". - Almaty. - Pp. 86-88. (In Russian)

Podol'nyy O.V. (1991) Podzemnyye vody kak komponent ekosistem aridnoy zony v usloviyakh tekhnogeneza: Avtoref. dis.... d-ra geol.-miner. nauk. [Underground waters as a component of ecosystems of an arid zone in the conditions of technogenesis: Author's abstract. Dis .... Dr. Geol.-miner. Sciences]- Tashkent. - P. 44. (In Russian)

Posokhov Ye.V. (1969) Formirovaniye khimicheskogo sostava podzemnykh vod (osnovnyye faktory). [Formation of the chemical composition of groundwater (main factors)]- L.: Gidrometeoizdat, 1969. - P. 334. (In Russian)

Sochava V.B. (1978) Vvedeniye v ucheniye o geosistemakh. [Introduction to the theory of geosystems] - Novosibirsk: Nauka. - P. 398. (In Russian)

Solntsev V.N. (1981) Sistemnaya organizatsiya landshaftov. [Systemic organization of landscapes]- M.: Nauka. - P. 329. (In Russian)

Uil'yams V.R. (1947) Pochvovedeniye. [Soil Science]- M.: Sel'khoziz. - P. 230. (In Russian) 